\title{
Pilgrimage to Sunan Ampel: From "Communitas" to Contested Space
}

\author{
Achmad Fawaid ${ }^{1}$
}

\begin{abstract}
Abstrak
Tulisan ini mencoba menganalisa tentang pencitraan Sunan Ampel, termasuk makam, mesjid, sumur, dan Pasar yang berkaitan dengan Sunan Ampel dalam tiga direktori online di internet, dan pengaruh pencitraan tersebut terhadap bagi para pengunjung yang pernah menggunakannya. Dengan menggunakan konsep "Komunitas, liminality dan tiga ruang" dari Turner, situs Sunan Ampel dianggap sebagai ruang perpaduan antara pariwisata dan ziarah yang tidak jelas, kabur dan dicap kurang baik. Hal ini juga berdampak pada adanya anggapan bahwa situs tersebut merupakan tempat mistis, berbau kematian dan kultus terhadap Sunan Ampel. Proyeksi wisata terhadap situs tersebut juga akan berdampak pada nilai ekonomis dan historis. Akibat dari proyeksi tersebut adalah munculnya paradoks antar fungsi ziarah dengan apa yang terjadi di lapangan. Niat ziarah yang suci akan bergeser menjadi pariwisata, perdagangan, migrasi, ekspresi nasionalisme, munculnya diaspora, maysarakat yang suka takhayul dan hal buruk lainnya.
\end{abstract}

Kata Kunci: Sunan Ampel, Citra, Komunitas, ruang persaingan

\begin{abstract}
s
This paper is to analyze "image" of Sunan Ampel, including Ampel tombs, mosque, wells, and market, projected within the three online directories and the possible impacts of this use on different visitors. By using Turner's concept "communitas", liminality, and third space, Sunan Ampel site is also considered as a space in which the ties between tourism and pilgrimage are unclear, blurred, and poorly classified. This relationship has also resulted in possible potentialities on how that site has projected mysticism, death, and apophantic nature of Sunan Ampel. The changing projection of the site will be also highlighted in the context of economic and historical spheres. The consequence of such interpretation is that Sunan Ampel could be empty vessel in which the interpretative battle and representations are continuously contested. "Sacred pilgrimage" to Sunan Ampel, finally, overlaps with tourism, trade, migration, expression of nationalism, creation of diasporas, imagining communities, and others.
\end{abstract}

Keywords: Sunan Ampel, image, communitas, contested space

${ }^{1}$ Gadjah Mada University 


\section{A. Religious Framework Of Sunan Ampel}

Sunan Ampel was the spiritual force behind the founding of Java's first Nusantara Islamic kingdom in Demak. As the origins of Sunan Ampel, it is believed that his father Syekh Maulana Ibrahim Asmorokondi, who came from the Middle East or somewhere in Central Asia, married a princess of Campa, from where the young Raden Rachmad (Sunan Ampel) arrived in Java early in the 15th century. He died in A.D. 1479 and was buried at Ngampeldenta, Surabaya, East Java.

The tomb of Sunan Ampel is one destination of Wali pilgrimage in Java. Around the area of his tomb, there are other tombs of his guardians and students. One of them is Mbah Soleh, who allegedly died for ninth times, and therefore nine tombs were built for him.

Near the tomb is an old well built by Sunan Ampel and his students. It is believed that the well will give a 'blessing' (berkah) for whoever drinking it. Additionally, a mosque of Sunan Ampel was upright there. It has 16 pillars of teak wood. Each of them is 17 meters without sequel woods. These are very tight until now, even they were more than 6000 years old.

It is believed that this mosque has its own 'goodness' (karomah). It was historically recorded that in the colonization period, the colonizers sporadically bombarded Surabaya which caused a wide destruction. But, this mosque was not broken. From time to time, many domestic and foreign people have visited this 'sacred' place, either for outing or religious travel (ziarah).

Around the site, a local market, namely Kampung Arab (A Hamlet of $A r a b)$, was built to provide another colorful sight. At this place, many books, posters, and other items can be easily found for sale. Some of the sellers have claimed themselves as a part of "authentic" trader generations in the area of Ampel, Surabaya. Kampung Arab has provided not only as traditional market, but also a Middle East culinary. There are many foods having ingredients of spices and flesh, a unique provision of Middle East.

Due to this reason the local and district governments of East Java have regularly attempted to 'restore' this site. The tomb of Sunan Ampel, with its mosque and other facilities, was listed as one of cultural and religious reservation in East Java.

\section{B. Disscusion}

\section{Different Ads, Similar Goal}

"Wali Songo Pilgrimage", it is one of headlines in an advertisement website EastJava.com. In the main menu, fantastic words are displayed in the top of page "East Java, Indonesia: A Tropical Paradise in the World". As a travel website, this could be regarded as a complete online directory in which the visitors will see diverse menus navigating them into the tourist information based on the regencies and cities in East Java, ranging from Surabaya to Sumenep.

If one is going into a navigator menu "A Beauty of East Java", it is found "pilgrimage tours" under other information option. Going into the link, one will find a new page of pilgrimage tour in East Java. Go to "Wali Songo Pilgrimage", there are some pieces of short information about Wali Songo (the great nine saints), especially those who fought for Islamic missionary in Indonesia. The primary wali (Maulana Malik Ibrahim, Sunan Ampel, Sunan Giri, Sunan Bonang, Sunan Drajat, Sunan Kudus, Sunan Kalijaga, Sunan Muria, and Sunan Jati) and other wali 
(Prapen, Ibrahim Asmoro, Sunan Bejagung, Syekh Siti Jenar, Tembayat, Pusponegoro) were listed next to the other links, such as holy places, holy mosques, and others.

Interestingly, under the menu "holy places", only Kampung Arab was provided. In the light of such advertisement, Kampung Arab is believed as one of sacred place from which the travelers and tourists can see "colorful selling" there. Some pictures, such as old books, tales, legendary pictures, mosque, and shopping activities, are displayed. However, it is a few of information provided in this menu, as well as information of each Wali Songo.

In a menu "About Us", it is informed that EastJava.com is the greatest tourism portal in East Java. It operated online since 1998, and now has more than 5000 pages, 2000 photos, 50 high rest maps, 500 clip videos, and 200 articles about travel destination in East Java. It is also clearly mentioned that "this portal is dedicated to compete with other foreign websites aimed to attract tourists from aboard". There are no clear data found in relation with the owners of this website. But, the website groups of EastJava.com have indicated that this website is sponsored by Indonesiacommerce.com, a huge site which focused on e-commercial promotion in many fields, including tourism. It is a kind of website which is intended to attract tourists and travelers going to East Java by facilitating a lot of advertisements, contacts, and information about tourism.

Another source is e-newspaper Travel.okezone.com. Under the menu "Indonesiaku", many articles about tourist destination are provided. This website is easy-use due to the menu "search". One simply types a specific destination or site, this website will display some articles about it. In addition to "Indonesiaku", there are other interesting menus, such as "Jelajah", "Pelisir", "Video", "Potret", and "Booking Hotel". If one wishes to get a collection of travel diaries, it is simply to click "Jelajah" (Expedition).

The articles published in "Jelajah" have issued traveler's experience in a visit to specific site. However, the style of such report is not narrative, but a kind of feature. The menu "MyJourney" in the top of site will provide 'more' narrative stories about personal travel experiences. By reading journey articles and features in Travel.okezone.com, readers are invited to have a travel as if they are in the realtime. Like as EastJava.com, this travel website also displays many advertisements and updated information about tourism, but with broader destination, not only East Java, but also all around Indonesia. Travel.okezone.com was an independent online site under Okezone.com, an entertainment website established on December 29, 2006. The owner is Media Nusantara Citra Ltd. (MNC), a corporation which managed other business media, such as RCTI Channel, Sindo Newspaper, and Sindo Trijaya FM.

To enrich these journey insights, Yudasmoro's travel essay "Simbol Harmoni Surabaya" (A Symbol of Surabaya's Harmony) will be used to show the different points of view in positioning Sunan Ampel in the light of religious harmony. It will give a unique perspective on the ways Sunan Ampel is perceived by a travel writer. Visiting to his travel blog, Yudasmoro.net, one will consider about how Yudasmoro has personal enjoyment as traveler-writer. There are menus indicating it, such as "Travel Photo", "Culture", "Journey", 
and others. He is also an author of books Fast Food United and Travel Writer.

\section{Colorful Displays Of Sunan Ampel}

As indirectly mentioned before, both EastJava.com and Travel.okezone.com have displayed Sunan Ampel in different ways, but for one aim: getting tourists' interest. For the case of Sunan Ampel, EastJava.com uses a number of functional attributes in English. It emphasizes traditional and Middle East images of Sunan Ampel, such as $a$ number of holy books, Indian traders, shopping activities, and great mosque at Ngampel. This website is seemingly dedicated for foreign tourists, not only by providing traditional images (something mystical for foreigners), but also by using English as main language. Moreover, in the "About Us", this website has clearly informed that it has similar goal as well as the foreign travel website has, i.e. "to bring foreign tourists in East Java" (mendatangkan turis dari luar negeri ke Jawa Timur).

Meanwhile, Travel.okezone.com is more localized in the ways of using Indonesia language to attract domestic people. This website uses the images of Sunan Ampel in more modern ways than EastJava.com. It could be seen on the level of brightness in each image in which Travel.okezone.com uses sharper images in displaying the mosque and tomb of Sunan Ampel. However, EastJava.com has preferred to use images with brown and gray colors, displaying the past time and mystical atmosphere.

In the light of semantic use, both of these sites have used a number of similar functional attributes, e.g. holy place of Muslim Missionaries, Beauty of East Java, colorful Kampung Arab, holy mosques in EastJava.com, or "Wisata Religi ke Makam Sunan Ampel" (religious travel to Sunan Ampel), a great mosque with its own blessing (masjid yang membawa berkah tersendiri), the second biggest mosque in Surabaya (masjid terbesar kedua di Surabaya), original Arabic meal (makanan asli Arab), sacred well (Sumur Keramat), and enjoying the comfortable and quiteful pilgrimage (menikmati ziarah yang nyaman dan tenang). All in all, it is possible to identify five functional attributes in the websites: (1) shopping facilities; (2) scenery/natural attractions; (3) tourist sites/activities; (4) historic sites; and (5) infrastructure.

As a comparison, Yudasmoro's article "Simbol Harmoni Surabaya" (A Symbol of Harmony in Surabaya) has revealed another insight of Sunan Ampel. Different from the two travel websites mentioned before, Yudasmoro writes a travel essay about his visit to Ampel mosque and Kampung Arab. Compared from the travel websites, Yudasmoro has used more attractive remarks to describe his amazement of Sunan Ampel. Moreover, Garuda Inflight Magazine-Middle East Service has published his essay on its edition April-May 2011.

His capability in writing travel experience attracts the readers by using some functional attributes with different points of view. His essay emphasizes the scenery and architecture, e.g. 'luxurious interior mosque of Sunan Ampel', 'traditional market with the brown and gray bookstores', 'a pedicab', 'worship market', 'Javanese gateway of Sunan Ampel', 'Middle East meals', etc. Subsequently, tourist sites/activities and historic sites are mentioned, e.g. you can see a legendary mosque of Sunan Ampel, a local discussion about diverse issues which enliven its interior and square, the mosque with marble layers which refrigerate the temperature of its interior floor, and others. 
With regard to the psychological attributes, Yudasmoro stresses the friendliness of the population and the quality of service: the residents are trader but loyal to maintain the tradition of ancestor, they are very kind, they live in harmony for years, they have Arabian face with East Java accent, etc. The different cuisine and stuff from Middle East are exemplified by means of pictures of local dishes: Some stores sell any kind of medicine from Middle East which is allegedly rooted from Islamic civilization in the period of Muhammad, the unique fruit is date (kurma), the foods from Egypt with different forms, Taliban cap which is difficult to find in elsewhere in Indonesia, etc.

\section{Possible Effects Of "Image" Sunan Ampel}

Given the foregoing, it is possible to consider that EastJava.com and Travel.okezone.com seeks to establish a mental picture of Sunan Ampel as a very unique tourist destination, which is evident by its impressive architecture, important business center as well as in its diversity in architecture, pictures, shopping, and scenery. Furthermore, by visiting at EastJava.com and Travel.okezone.com, one will see Sunan Ampel as a religious travel site characterized by a blend of old and new, traditional and modern nuances, East and West.

Meanwhile, concerning the psychological holistic impressions of Sunan Ampel, Yudasmoro's travel note seeks to establish certain atmospheres and/or feelings surrounding the site, despite the absence of the words 'atmosphere' and 'feeling' in his note. Primarily, his essay describes Sunan Ampel as having a vibrant and exciting atmosphere due to not only Middle East environment in Kampung Arab, but also a harmony among people/traders: This hamlet of Arab (Kampung Arab) takes place in next to the hamlet of China (Kampung Cina/Pecinan) with more luxurious building. However, the housebusiness building (ruko) of Kampung Arab has bigger gateway than Kampung Cina, with colorful Oriental paint. By using these remarks, Yudasmoro wishes tourists to have expectation about a harmonious destination with relaxed atmosphere.

The point is that despite of different ways used to describe Sunan Ampel, EastJava.com, Travel.okezone.com, and Yudasmoro's essay would invite tourists to receive an instant authentic feeling of romantic and exotic past, and they promise an authentic atmosphere in a modern environment. As Taylor theorized, there is a general agreement among tourism researchers and academics that a quest for authenticity forms the basis of many tourists' choice of destination. Thus, the creation of an authentic atmosphere may be appealing to potential tourists. However, in the attempt to promote an authentic atmosphere, those descriptions are actually promoting an attraction, which has been staged by the tourism industry as 'staged authenticity' (Taylor, 2001: 14).

In addition to the above described atmospheres and feelings possible to experience during a visit to Sunan Ampel, the tourists may also take a break from the vibrant and ever-changing situation, and experience a fresh and natural atmosphere. Travel.okezone.com exemplifies, Then, local community has attempted to build the great mosque and tomb of Sunan Ampel in such a way the visitors are possible to have comfortable and quite praying and pilgrimage; the mosque with marble layers which refrigerate the temperature of its interior floor; etc. Thus, despite the emphasis on 
Sunan Ampel as a center of business center Kampung Arab with that includes, this website also highlights a feeling of beautiful lush greenery nestled among the busy metropolis center.

Finally, the website conveys a friendly and welcoming atmosphere: friendly people, local community, etc. In addition, the reader of the website will sit back with a feeling of local population that is very much part of the destination's identity: In Yudasmoro's essay, What makes this hamlet unique is its people living in harmony. With this statement, he stresses an importance of Sunan Ampel as image of 'religious' destination.

\section{Sunan Ampel As "Third Space"}

In Image and Pilgrimage in Christian Culture, first published in 1978, Victor and Edith Turner highlighted a dimension of religious experience that had scarcely received attention in the field of anthropology (for instance, Coleman, "Do You Believe in Pilgrimage?", 2002). The work presented a unique anthropological contribution to the field of pilgrimage studies, providing a hermeneutical lens for interpreting pilgrimage experience through the concepts of liminality and communitas. In brief, liminality concerns being "inbetween" within a rite of passage, as a person moves from one social state to another. During a rite of passage (van Gennep, 1960: 3), a person enters a phase of separation from a previous group, which is followed by an "inbetween," or liminal, phase during which many aspects of life are likely to go through a process of change or distortion.

Victor Turner recognized communitas as an experience of oneness or unity felt by those sharing a rite-ofpassage experience. He compared it with Martin Buber's "I-thou" concept: a sacred experience of mutuality with another. Communitas therefore describes a model of sociality and a way of experiencing unanimity with other human beings that exists beyond the riteof-passage experience. Another aspect of communitas, the experience of "antistructure," contrasts with the usual norms of society, or "structure." Within the realm of antistructure, commonplace social distinctions disappear and individuals relate to each other as equals. Victor Turner saw the structure/antistructure cultural dynamic as central to the organization of human society; human beings flourish by engaging in a communitas experience and then return to everyday structure renewed and rejuvenated (Turner, 2006: 129).

By positioning Sunan Ampel site as "communitas", one will find that this site has transcended itself to the lived-in and planned world, a place which is often referred to "third space". There are many 'modern' events held in Sunan Ampel, such as circumcision ceremonies, the parade of Ampel villagers from homes at Kampung Margi to the mosque, and others. At the entrance of the Ampel mosque hawkers line both sides of the alley way selling all kinds of goods from perfume, to sarongs, black caps, Muslim clothing, rosaries, to Zamzam water from Mecca, and other prayer needs. There are also hawkers selling Ampel specialty snacks and food like prawn cakes to Arabian curry.

These facts have brought us into a sense of "third space" in which people from Jakarta, Bali, Banjarmasin, Yogyakarta, Manado, Lombok, Singapore, Brunei Darussalam, and even Kuala Lumpur can encounter between each other to take a spiritual journey in Sunan Ampel. They are also coming from different social status, but when they have worshiped in Sunan Ampel, 
these social statuses have been blurred. In that site, they encounters with their fellow travelers, of varying nationalities and spiritual persuasions, along the route. It is a space in which people have taken temporary transition away from mundane structures and social independence into a looser commonality of feeling with fellow visitors. It is a space in which Sunan Ampel as sacred place and 'mundane' destination is poorly classified.

What so-called "spiritual journey" to Sunan Ampel, therefore, is not really spiritual, because there are many other human beings that exists beyond the rite-of-passage experience, there are also many stores which provide 'spiritual devices' they need to praying. This site is also possible to be "communitas" with anti-structure where it is difficult to find out social structure tied with Sunan Ampel site, because many Muslims, or even non-Muslim tourists, come and leave. It is a space where social encounter, not social structure, has happened. By "encounter", I refer to a condition in which people get involved with other activities in temporary time, and only their traces have been remained.

Another reason is that "pilgrimage" to Ampel site has been voluntarily undertaken by participants. If Mecca is regarded a center of pilgrimage and the only place in which people have been obligated to pilgrimage, the shift to meaning "pilgrimage" by displacing it with Ampel site will take a form of new movement on the ways people can pilgrim to other spaces without going to Mecca. The other places are possible to include the religious sites people regarded as "sacred", such as Gunung Kawi, Walisongo sites, or others in which they get possible feeling of "pilgrimage" as like as to Mecca. Sunan Ampel site, in this case, is a liminal space which suggests alternative ways for people to perceive "pilgrimage" not merely in the center of place, but rather in the in-between space.

\section{Potentialities Of Pilgrimage To Sunan Ampel}

There are some "potentialities" of pilgrimage mentioned in Image and Pilgrimage, and this section will reveal such potentialities regarding with image of Sunan Ampel. These potentialities are mysticism in pilgrimage, the theme of death, and apophantic awareness (encounters with God through the via negativa). These themes reveal further spiritual dimensions of liminality and communitas, and contribute to an understanding of why pilgrimage appeals to the human psyche. Mysticism and the theme of death are mentioned in Image and Pilgrimage and receive explicit attention in the Turners' broader corpus. The apophantic is an implicit theme within their work and is not mentioned by them directly.

\section{Mysticism of Sunan Ampel}

One of the gems of Image and Pilgrimage is an observation concerning the mystical nature of pilgrimage: "Pilgrimage may be thought of as extroverted mysticism, just as mysticism is introverted pilgrimage. The pilgrim traverses a mystical way; the mystic sets forth on an interior spiritual pilgrimage. For the former, concreteness and historicity dominate; for the latter, a phased interior process leads to a goal beyond conceptualization" (Turner and Turner, 1978: 33-34).

Sunan Ampel is one of the greatest Islamic saints in Java who spread Islamic teaching by adopting local and cultural mediations. It is the first pathway of syncretism between Java culture and Islamic religion. What so- 
called Islam kejawen is a central theme of such syncretism which is hitherto practiced by local people surrounding Sunan Ampel. The main characteristics of Islamic mysticism in Sunan Ampel are the existence of ancestor, ritual activities for getting talisman (jimat), or selamatan ceremonies.

In Travel.okezone.com and EastJava.com, Sunan Ampel is frequently called as Islamic ancestor of Surabaya. By ancestor (leluhur), I refer to those who have noble attitudes (sifatsifat luhur) in their lifespan, and for these reasons posterity will honor them by carrying out customary rituals (upacara adat). Muslims kejawen believe that Sunan Ampel is a moral leader whose the daily behavior or conduct is regarded religious model for people in their ways of speaking and conversation. Leluhur has taken a central position in Javanese cultures, including Surabaya.

I have experience a communitas in Sunan Ampel, and I found how modern and traditional people - even in vague definition-have practiced their own rituals in that site. I have often paid attention on certain people who seem to try getting berkah, jimat, or karomah, either in tombs or in wells of Sunan Ampel. They usually write some Javanese texts in a paper or bring some of used bottles to take waters from the well for a healing. The water or something they believe sacred is like a jimat (talisman) which in some ways gives a mystical medicine or defense in their daily life.

Some selamatan ceremonies are also held in Ampel site. Usually, selamatan (derived from Arabic salam or giving salvation) is taken with tahlil by saying La ilaha illa Allah together surrounding the tombs. It is important to note that this ritual is not similar as such as worship to Sunan Ampel; it is a ritual mediation (through Sunan Ampel) to pray and worship God. It is like a belief that when Muslims pray in the front of Abraham's footprint in Mecca, their prayers are believed to be more fulfilled.

These symbolic images of Sunan Ampel are symbolic language of mysticism. Sunan Ampel invites a wandering, a praying among the images. The link between mysticism and pilgrimage is a topic for comparative dialogue across religious traditions. It is also a meeting point for secular and religious dialogue, as exploration of the mystical dimensions of pilgrimage may expose the unrecognized spiritual dimensions of alternative forms of pilgrimage. This is especially apt given existing and ongoing research into pilgrimage and tourism.

\section{Death in "Pilgrimage" to Sunan Ampel}

In an article written three years before Image and Pilgrimage was published, Victor Turner explored the theme of death in the context of pilgrimage in the salvation religions, describing pilgrimages as "full of symbols and metaphors for death" (Turner, "Death and the Dead," 1992: 30). For Victor Turner, this firstly manifests itself through a connection with a dead founder, saint, or martyr associated with the pilgrimage site. Secondly, embarking on pilgrimage involves passing into a liminal or threshold time that involves "metaphoric" death on several levels. This passage occurs through separation from normal social existence, with the dissolving of social rank between fellow pilgrims, and through the liminal nature of pilgrimage, which involves an "inbetween state of life-in-death" (Turner, 1992: 30, 47). Such death, comparable to "mystical death," is viewed positively as a form of regeneration, and is equivalent to experiences of metaphorical death in indigenous rituals (Turner, 1992: 32-33). 
These aspects are very much evident within contemporary pilgrimage practice, as expressed by the veneration of saints and the pilgrimage-like tradition of remembering the dead. Sunan Ampel is Islamic saint or martyr associated with his tomb. People have visited to mosque, wells, and tombs of Sunan Ampel as their attempts to connect with the dead founder. Such effort is usually practiced by Muslim kejawen who believe that by providing ritual gifts, they can be possible to connect with soul's death of Sunan Ampel. The gate guardians (juru kunci), for example, have usually told their spiritual experience when meeting a spirit, soul, or something sacred regarding with Sunan Ampel. Some people also describe how they have dream about Sunan Ampel after praying for days and months in that site.

There are also many stories about Sunan Ampel's students. The clear instance is Mbah Soleh's death. It is allegedly known that he was died for nine times. For this reason, the nine tombs were built for him. Mbah Soleh is the most loyal student of Sunan Ampel, whose the job is a cleaning servicer for the mosque of Sunan Ampel. Their visits to Mbah Soleh's tombs are intended to pray to Allah for getting healing. It is a case of pilgrim from Pasuruan, which his child is dumb, and they were suggested to pilgrimage to Mbah Soleh. They are asked to pull out grasses on Mbah Soleh's tombs, and eat them. After a few of days, his child can fluently speak without such disease. (Source: "Kisah Sembilan Makam Mbah Soleh di Masjid Sunan Ampel," http://news.okezone.com/read/2011/08/1 2/345/491244/large)

Revering such dead may invoke a sense of communitas. The memorials of Ampel's death in Surabaya attract many visitors from different places each year. Some of them visit to get karomah and barokah from Allah through praying in the mosque of Sunan Ampel, and some of them visit to witness the tombs as religious museums of the Sunan Ampel's death which are possible to provide them a state of life-in-death. Victor Turner described pilgrimage as "a rehearsal of the pilgrim's death" (Turner, 1992: 35). The need to revere the dead in pilgrimage activity perhaps stems from a need to confront and accept human mortality.

\section{Apophantic "Pilgrimage" to Sunan Ampel}

Pilgrimage involves a process of dying to oneself in order to find oneself (Turner, 1992: 47). This mystical dimension of pilgrimage, whether experienced on pilgrimage to particular sites or through a personal inner journey, involves confronting the self at a deeper level, often through an experience of the apophatic. The apophatic concerns a spiritual dimension accessed through what medieval Christian thinkers such as Bonaventure called the "spiritual senses" (Cousins, 1978: 3). God is found in negative experience-darkness, or the via negativa. This contrasts with cataphatic experience, which refers to an encounter with God through positive experience. "Death" within the pilgrimage context may potentially reveal encounters with God through negative experience.

The apophantic is an implicit theme in the Turners' work. In her autobiography, Edith Turner describes "in-between" experiences during her ongoing life pilgrimage that may be interpreted as apophantic. Ronald Frankenberg also refers to the Turners' dark-night-of-the-soul experiences (Frankenberg, "Foreword" to Heart of Lightness, 2006). It can be seen on the ways people pray, recite Quran, and read shalawat, for invoking themselves into 
the deep experience of encounter with God. The mosque, wells, and tombs of Sunan Ampel provide as medium through which we can see ourselves as others in front of other people, and they also see us the others for them. God, in this case, is the Wholly Other with which we are possible to encounter through praying inside or sacred journey to tombs of Sunan Ampel.

It is what Turner has called for a communitas, in-between. We are in between; we are negatively defined-not contradicted-as neti...neti: neither this nor that. We are thus opened up to new experience and meaning making such that we can work and play well with Others as we see ourselves as Others, too (Killinger, 2009: 162-164). This inbetween condition gives many benefits, such as joy, healing the gift of 'seeing', mutual help, religious experience, the gift of knowledge, long term ties with others, and so on (Turner, 2004: 146). Some of people have prayed inside the mosque of Sunan Ampel for days and months, and they acknowledge that they can feel such 'negative' experience. For another instance, many students, especially from SMA Ta'miriyah Surabaya, visit in groups to Sunan Ampel for study tour as well as religious travel for their preparation to take a national final examination. It is believed that praying in Sunan Ampel will give them such kind of the gift of knowledge.

\section{Economic And Social Contestation In Sunan Ampel}

Pilgrimage exists within a rapidly changing society, and it embraces both tradition and change. On the one hand, pilgrimage is an ancient practice, mandatory in some major world religions and voluntary in others. On the other hand, it is subject to economic, political, social, and religious forces of global change. How can the Turnerian pilgrimage paradigm be utilized given some of the inherent complexities resulting from changes in Sunan Ampel site, the interplay between pilgrimage and tourism, and economic and social changes at that site?

\section{Sunan Ampel and Economic Contestation}

There are huge effects of Sunan Ampel as religious tourism on economic development in Surabaya. The existence of Kampung Arab, for instance, has provided as a complex location of culinary, souvenirs, and accessories in which we will find a large market in the sense of Middle-East situation. In some ways, it has indicated a sense of communitas in Victor Turner's term, where Sunan Ampel site become liminal space in which social and economic activities are engaged with religious ones.

However, the local government's initiative to design Sunan Ampel site not only as religious site, but also as tourist destination, has influences on much discussion about the desirability of Sunan Ampel site as a strategy for economic development. It has also complex external transformations: technological change, such as cheap air travel and internet booking system; developments in capital, including the growth of worldwide hotels, travel agencies, and personal finance organizations, such as credit cards; the widespread growth of the 'romantic' gaze so that more people wish to isolate themselves from existing patterns of mass tourism; the increased fascination of the developed world with the cultural practices of less developed societies; the development of tourists as a 'collector' of places often gazed upon and experienced on the surface; and the emergence of a powerful interests 
promoting the view that tourism has major development potential (Urry, 2001: 73).

EastJava.com has provided a special page of Sunan Ampel site, not only in menu "Pilgrimage Tours", but also in "Surabaya Tourism". There are no such as thing a Sunan Ampel promoted only as religious site, but a tourist destination from which financial transactions can be resulted. In this page, one will find a easy way to make booking hotels, ticket reservation, travel services, and even investment. There are many hotels built by adopting mosque of Sunan Ampel's design; there are many stores which identified as the center for Sunan Ampel souvenirs, and so on.

In Kampung Arab, for instance, there is a store, namely the Gubah Ampel Suci market, which offers all kinds of goods from clothing to perfumes, dates, foodstuff, to all sorts of accessories both large and small that are usually bought as souvenirs by those who are on haji pilgrimage. One will find this market adopting an image of 'sacred' Sunan Ampel to be more interested than 'secular' stores.

The image of Sunan Ampel is used to attract tourists in the pure connection with Sunan Ampel. By doing so, the boundaries between 'home' and 'away' have been perforated, blurred. Tourists to Sunan Ampel are those who find themselves as "diasporic traveler."

\section{Sunan Ampel and Social Contestation}

Another interesting development has been the attempt to classify Sunan Ampel site in the context of heritage and root seeking tours (Kreiner, 2010: 445). Sunan Ampel site can be read not only as religious, but also historic site. It is due to the historical fact on which the story of Sunan Ampel as one of National Patriot of Indonesia has been based. However, his tomb today is shaped into a successful tourist destination commemorating a remembered past, not only about Sunan Ampel, but also about other sites, such as Majapahit and Mecca.

The minarets that stand 50 meters high are a unique feature of this mosque from where the adzan (call to prayers) is sent out. The large hall with its large dome follows the Javanese pendopo (or open hall) style that marks the greatness of Majapahit Empire, whose seat was at Trowulan. Majapahit the time was also instrumental in spreading Islam together with Sunan Ampel. Another historical instance is the Ampel mosque which has five main gates called Lima Gapuro symbolizing the 5 Pillars of Faith of Islam. When you enter from the south at Sasak Road you will pass the Gapuro Munggah or Munggah gate, where you will pass the town's market place, which resembles the Seng market by the Haram mosque in Mecca, reminding the faithful to go on the haj pilgrimage when able. By going to Gapuro and Mnuggah Gate, it is possible for people to have "tourist's gaze" on Majapahit and Mecca, otherwise than Sunan Ampel.

These findings indicate the creation of a strong sense of unity, which brings us back to Turner and Turner (1969) model of ritual process and the ways in which ritual helps create and sustain group cohesion. Ioannides and Cohen Ionnides (2002), which examined patterns of Jewish travel in the United States, described them as "Pilgrimages of Nostalgia". It is also true for Sunan Ampel site, due to it is possible produced as a commoditized object of the nostalgic past.

\section{Further Projection In Sunan Ampel:}

\section{From Spatial To "Virtual" Pilgrimage}


By taking Sunan Ampel as communitas or "third space", it brings our attention to another paradigm 'contestation' in Eade and Sallnow's term. In some ways, the idea of contestation can be a critique of communitas which tends to just idealize discourse about pilgrimage rather than an empirical description of it (Eade and Sallnow, 1991: 5). Eade and Shallnow present pilgrimage as a capacious arena capable of accommodating many competing religious and secular discourses.

In spite of a critical question on the possible things which is not as contested one in such postmodern era (Coleman, 2002: 357), Contesting the Sacred (1991) is part of, and has contributed to, a renaissance in studies of pilgrimage. The contestation paradigm reveals its semiotic roots in the argument that varying 'discourses' can be housed under a flexible sacred canopy. One consequence of this view is that pilgrimage is presented more as a context for the representation and reinforcement of ideas than as involving embodied practices.

The interpretative battle has been a part of projecting Sunan Ampel as the contested space in which representations of that site are always being consistent among parties. It has been implicitly mentioned that Sunan Ampel could be differently used by different people, either in reading different online directories, or in visit to this site. This section is intended to clearly provide a multi-faceted meaning of Sunan Ampel not only as a strip away mundane conflicts and assumptions (as in Turnerian paradigm), but rather a space providing exceptionally accommodating (and possibly amplifying) contexts for them to be expressed.

As sacred place, Sunan Ampel is consumed by religious people who believe that this site will favor spiritual sense, a rites of passage, negative experience, and metaphoric feeling of death. They have assumed that Sunan Ampel should be perceived only for religious purposes. It will be functional only if people employ Sunan Ampel in giving berkah and karomah, and as mediation through which they are possible to pray God. Every year, even every day, there are lots of Muslims coming to search for religious benefit.

Sunan Ampel is also possibly considered as cultural heritage. It will immediately bring us to historical and cultural building of tombs, wells, and mosque. For instance, in Ampel mosque, the sixteen pillars which have 17 meters for each of them has meaning: 16 letters in kalimah syahadat and 17 for amount of Islamic prayer prostrations. Around the mosque, in Sasak road, there are 5 main gates symbolizing 5 pillars of faith of Islam, i.e. Gapura Munggah, Gapura Poso, Gapura Ngamal, Gapura Ngadep, and Gapura Paneksen. In some ways, these cultural symbols could create 'tourist gaze' to look Sunan Ampel without involving their spiritual sense. It is also a reason why local governments are in this position to make a bridge between local people's need to employ Sunan Ampel as their spiritual space in one side, and foreign tourists to 'capture' it as cultural museum of Sunan Ampel. For local government today, Sunan Ampel is more culturally signified than religiously one as a part of cultural preservation (cagar wisata).

Kampung Arab, meanwhile, has been another insight to perceive Sunan Ampel, not merely as religious or cultural site, but also a part of central business in Surabaya. Kampung Arab has provided people a new way to see traditional Middle-East market nearly from Jembatan Merah Plaza, one of the greatest malls in Surabaya. Specifically, a traditional market in question is well 
known as Gubah market (pasar Gubah), which is historically noted as point of departure since 1420 for Arab and Chinese traders. Even popularly called as Kampung Arab, "there is no real Arab here! Only Indonesian!” said H. Helmi, one of elders at this hamlet. Most of them are Arab descendants, whom have Arab fathers and Indonesian mothers. In Indonesia, unlike in Arab, motherland is more appropriated than fatherland in the system of kinship. It has been cohesion to attract people for seeing a kind of 'authentic' Arab atmosphere in buying their daily spiritual needs in Gubah market, Sunan Ampel.

However, for tourist travels, Sunan Ampel is one of the best commoditized products for religious travel. Travel.okezone.com and EastJava.com, for instance, have used Sunan Ampel to redistribute their advertisements of booking hotel, travel services, train tickets, and others. The crucial element for such online tourist directories is not merely a historical or spiritual story of Sunan Ampel, butmost importantly-a product of commercialized business. If local businesses employ Sunan Ampel in Gubah market, such online directories take advantages of Sunan Ampel for offering their affiliated business institutions.

For being personally involved with having 'pleasure' to read Sunan Ampel from the distance (from Internet), pilgrimage is probably perceived as a practice beyond 'normal' definition of religious one. By doing so, pilgrimage to Sunan Ampel is not considered only as a visit to the location, but also a 'online pilgrimage' to that space. When the Internet is increasingly seen as more than a space for information, but a space that is encouraging spiritual and social connection, it will make us possible to have new forms of spiritual exploration and religious observance (Hill-Smith, 2011: 238). To engage with Islamic faith and culture in Sunan Ampel, individuals can do so on virtual Ampel (it is as like as, for instance, "Virtual Jerussalem" in http://www.virtualjerusalem.com/).

However, it is probably difficult to implement this experiment due to the fact that Indonesian people still have a strong awareness of pilgrimage to the 'real' destination. Even though it is uncommon in (Muslims) Indonesia, such venture has been initiated by Pesantren Virtual (www.pesantrenvirtual.com) to provide a "communitas" in different way, and this idea is possible to be undertaken in the context of pilgrimage

By locating the image of Sunan Ampel as 'contested', one will construct it not merely as a vacuum space in order to differentiate pilgrimage activity from the everyday, but also religious 'void', an 'empty vessel' that is open to the assumptions that will be poured into it by constituencies of pilgrims. As a blankness, Sunan Ampel is contested among peoples who perceive it or who has directed it to the certain goals. The contestation of Sunan Ampel is finally depending on who have interests to look at that site and for what this vision look like.

\section{Closure}

Having analyzed the different components of Sunan Ampel found in these websites, the identification of the image of Sunan Ampel is possible. Firstly, Sunan Ampel's image consists of both functional and psychological attributes, and the psychological attributes slightly exceed the functional indicating an effort to distinguish Sunan Ampel from other destinations by highlighting its psychological characteristics, which may be difficult to find elsewhere. 
Secondly, the analysis of the functional and psychological impressions indicated an emphasis on projecting an image of an exciting and a friendly dynamic destination, where the tourist will find diversity and blend of cuisine, shopping, architecture, and in particular culture. This diversity means that there is something for everyone in Sunan Ampel. Thirdly, analysis of the common and unique features demonstrated that the image of Sunan Ampel can be described as being both unique. The image is unique, because there is an emphasis in the brochure on unique features such as Kampung Arab, diverse medicine from Middle East, different races living in harmony, and the like.

Thirdly, it has now been established that the image of Sunan Ampel is possible to attract and affect different groups that visit or use the site. Shortly speaking, projecting the image of Sunan Ampel functions as-what Lindsay Jones (1995: 213) calls-“the strategy of allurement". Foreign tourists will be possible to see Sunan Ampel in authentic ways because EastJava.com has clearly provided the past projection of images, such as old tales, Indian pictures, and historical notes of Sunan Ampel. However, they will be surprised by looking at Travel.okezone.com in which Sunan Ampel consists of modern views with green scenery and busy shopping activities in Kampung Arab. However, both of them are providing a bridge between the past and present atmospheres of Sunan Ampel.

Meanwhile, if tourists use Yudasmoro's travel essays, they will find personal and excited experiences in a visit to Sunan Ampel due to its promises for harmonious (as well as economic) atmosphere. Yudasmoro gives more stress on the harmony among Kampung Arab and Kampung Cina (as two centers of business activity), without ignoring to project historical atmosphere of Islamic civilization nestled in Sunan Ampel. For religious practitioners, Sunan Ampel is a great site where they will find an authentic pilgrimage to the sacred tomb of Sunan Ampel, the mystical well of Sunan Ampel, and the great mosque of Sunan Ampel. These are great destinations which are possible to boost their desire for getting mercy (karomah) and blessing (berkah).

Fourthly, the image of Sunan Ampel has resulted in a logical consequence that this site becomes communitas (Turner and Turner, 1978), which refer to specific group dynamics which take place in an assembly of pilgrims. This encounter creates some possible potentialities, including mysticism, death, and apophantic nature of Sunan Ampel site. The mysticism of Sunan Ampel can be traced through people's belief in Sunan Ampel as their ancestors; the metaphorical death has been modified in mystical story of Mbah Soleh; and the apophantic nature could be seen on the ways people try to get a deep level of spiritual journey by praying at Sunan Ampel tombs.

Fifthly, there are many changes on how people define Sunan Ampel site in the sense of historical or economic development. This site was being economic destination for tourists in which they can encounter not only with spiritual situation, but also with the markets and stores in Kampung Arab. Such "third place" phenomenon has been more elucidated in visualization of Gapuro and Market which adopt historical stories of Majapahit and Haram mosque in Mecca.

Finally, Sunan Ampel is regarded as contested space due to its 'blank' image which provides an interpretative battle among different people for different purposes. Sunan Ampel is regarded as religious, economic, 
historical, cultural, or even virtual sites for those who can take their 'own benefits' of this site. Based on these purposes, it is clearly recognized that Sunan Ampel site could not really be a "pure place" for getting berkah, due to its dual-position as "third space", liminal space, in which the sacred place, cultural heritage, historical building, and the busy economic center of Surabaya have been there. It is a site where "God and money never sleep."

\section{Bibliography}

\section{Journals/Books:}

Coleman, Simon. "Do You Believe in Pilgrimage? Communitas, Contestation, and Beyond." Anthropological Theory 2. No. 3 (2002): pp. 355-368

Cousins, Ewert H. Bonaverture: The Soul's Journey into God, the Tree of Life, the Life of St. Francis. Mahwah: Paulist Press, 1978.

Eade, John., and Michael Shallnow (eds.) Contesting the Sacred: The Anthropology of Christian Pilgrimage. London: Routledge.

Frankenberg, Ronald. "Foreword" to Heart of Lightness. New York and Oxford: Berghahn Books, 2006.

Hall-Smith, Connie. "Cyberpilgrimage: The (Virtual) Reality of Online Pilgrimage Experience." Religion Compass 5, No. 6(2011): 236-246.

Ioannides, D., and Cohen Ioannides, M. "Pilgrimages of Nostalgia: Patterns of Jewish Travel in the United States." Tourism Recreation Research 27, No. 2 (2002).
Jones, Lindsay. Twin City Tales: A Hermeneutical Reassessment of Tula and Chichén Izá. Niwot: University Press of Colorado, 1995.

Killinger, J. "Communitas." In Encyclopedia of Psychology and Religion. Edited by D. Leeming, K. Madden, and S. Marlan, 162-164. New York: Springer, 2009.

Kreiner, Collins N. "Researching Pilgrimage: Continuity and Transformations." Annals of Tourism Research 37, No. 2 (2010): 440-456.

Taylor, John P. "Authenticity and sincerity in tourism". Annals of Tourism Research, 28, No 1 (2001).

Turner, Edith. "Rites of Communitas." In Encyclopedia of Religious Rites, Rituals, and Festivals. Edited by E. Salamone, 97-110. New York: Routledge, 2004.

Turner, Edith. Heart of Lightness: The Life Story of An Anthropologist. New York and Oxford: Berghahn Books, 2006.

Turner, Victor and Edith Turner. Image and Pilgrimage in Christian Culture: Anthropological Perspectives. New York: Columbia University Press, 1978/1995.

Turner, Victor and Edith Turner. The Ritual Process. London: Routledge, 1969.

Turner, Victor. "Death and the Dead in the Pilgrimage Process." In E. Turner. Blazing the Trail: Way Marks in the Exploration of Symbols, 29-47. Tucson: 
University of Arizona Press, 1992. First published in M. Whison and M. West, eds. Religion and Social Change in Southern Africa: Anthropological Essays in Honour of Monica Wilson, 107-127. Cape Town: David Philip, 1975.

Turner, Victor. "The Center Out There: Pilgrim's Goal." History of Religions 12, No. 3 (1973): 191230.

Urry, John and Jonas Larsen. The Tourist Gaze 3.0 (Third Edition). Thousand Oaks, California: SAGE Publications, 2011.

Van Gennep, A. The Rites of Passage. Trans. G. L. Caffee and M. B. Vizedom. London: Routledge and Keegan Paul, 1960.

\section{E-directories:}

"Holy Place of Muslim Missionaries." http://www.eastjava.com/books/ walisongo/html/places/ka.html (last access: October 19, 2013)

"Kisah Sembilan Makam Mbah Soleh di Masjid Sunan Ampel." http://news.okezone.com/read/2011 108/12/345/491244/large (last access: October 22, 2013).

"Tidak Ada Orang Arab Di Sini." http://sosbud.kompasiana.com/201 2/09/13/kampung-ampel$\%$ E2\%80\%9Ctidak-ada-orangarab-di-sini\%E2\%80\%9C486503.html (last access: October 24, 2013)

"Sunan Ampel". http://www.eastjava.com/books/wal isongo/html/walisongo/ampel.html (last access: October 19, 2013)

"Wisata Religi ke Makam Sunan Ampel".

http://travel.okezone.com/read/ 2011/08/01/407/486845/wisatareligi-ke-makam-sunan-ampel-1 (last access: October 19, 2013)

Yudasmoro, "Simbol Harmoni Surabaya”. http://yudasmoro.net/2012/12/05/si mbol-harmoni-surabayal (last access: October 19, 2013) 